\title{
The Case for Teaching Human Resource Management in Management Education: 13 Common Reasons
}

\author{
H.H.D.N.P. Opatha \\ Senior Professor \\ Faculty of Management Studies and Commerce, \\ University of Sri Jayewardenepura \\ opatha@sjp.ac.lk
}

\begin{abstract}
This conceptual study is a systematic attempt to fill a gap in the theoretical knowledge about reasoning the need of learning Human Resource Management (HRM) in Management Education (ME) in terms of having a synthesized description of reasoning and presenting a set of reasons to explain the need, and furthermore to solve an intellectual puzzle to uncover why HRM is to be taught in any qualification of Management at any level. Three research questions were formulated and they were answered by adopting a desk research strategy. 30 direct or indirect writings or explanations from 30 textbooks on HRM published by relevant authorities were examined, 13 common reasons were identified and listed, and based on the identified or derived common reasons, a content analysis was done. The study yielded findings consistent with the formulated three research questions and they are: there are at least 17 reasons for the case for teaching HRM in ME; it is possible to identify and list 13 common reasons which derive from or which are included in the writings considered for the study; and the top five reasons are (1) organizational success, (2) sustainable competitive advantage and organizational improvement, (3) every manager's vital responsibility and contribution to societal success (these two reasons got the same intensity of consideration being the top third reason), (4) enhancing professional life success, and (5) enhancing personal life success.
\end{abstract}

Key Words: Human Resource Management, Management Education, Reason, Teaching 


\section{Introduction}

Management Education (ME) is concerned with gradual process by which a person gains knowledge, skills and attitudes of Management through learning. ME is critical for organizational development and nation development, in particular for a country life Sri Lanka which badly needs competent, motivated, engaged, and committed professionals in managing. Right ME ensures the elimination of bad or mal management practices being existed in a considerable number of Sri Lankan organizations as bad or poor management is a major reason for low productivity (Akuratiyagamage and Opatha, 2004). ME refers to the system of teaching knowledge, skills and attitudes to people who aspire to become successful or more successful professionals in managing various functions, units, departments, organizations, or group of organizations. Human Resource Management (HRM) refers to the functional field of Business Administration or Organizational Management which is concerned with managing people at work. HRM refers to the policies, practices, and systems that influence employees' behaviour, attitudes, and performance (Noe, Hollenbeck, Gerhart and Wright, 2007). It is the efficient and effective utilization of human resources to achieve goals of an organization (Opatha, 2009).

It has generally been observed that almost all the qualifications in Business Administration or Management at Diploma, Higher Diploma, Bachelors, Bachelors Honours, Postgraduate Diploma, Masters, and Doctoral levels include HRM as a subject or a course, or at least as a module. It is true that there are specialized diploma, bachelor's degree, master's degree, and doctoral degree in HRM being offered by professional institutes, colleges, and universities.

Why should HRM be taught in ME? Most of the textbooks do not answer this question directly (Lussier and Hendon, 2013). Some of the recognized textbooks deal with the issue of importance of HRM indicating some reasons for the need of learning HRM. Surprisingly this question has been dealt with in only a few recognized textbooks on HRM (Bohlander, Sneel, and Sherman, 2001; Lussier and Hendon, 2013; Bohlander and Snell, 2017) in a direct way. It reveals a gap in the theoretical knowledge about reasoning the need of teaching HRM in ME in terms of having a synthesized description of reasoning and presenting a comprehensive set of arguments or reasons to explain the need. In addition, an intellectual puzzle exists to investigate why HRM is to be taught in any qualification of Management at any level.

\section{Research Questions and Objective}

Following research questions were formulated so that a systematic attempt could be made to find answers:

1. What are the arguments or reasons for the case for teaching HRM in Management Education which can be discovered from the existent literature?

2. Are there common reasons which necessitate teaching HRM in Management Education?

3. Can the common reasons be arranged in terms of importance? 
The objective of this research paper is to establish richly the case for teaching HRM in Management Education in terms of a distinct set of reasons from the existent literature.

\section{Method}

This research paper is a conceptual study which gives a theoretical contribution. In order to answer the two research questions systematically, a comprehensive literature survey was done by using the desk research strategy. Textbooks on HRM published by relevant authorities were utilized to find arguments about the need of teaching HRM in MD. Almost all the textbooks which were available to the researcher were used. Textbooks with the title Personnel Management which was existent before the title HRM became popular were too utilized. Textbooks are useful source of theory in a specific area covering a broad range of topics, furthermore covering a topic much more thoroughly than articles can (Sekaran and Bougie, 2016). Textbooks were developed by highly and appropriately qualified authors by using various works of various authors in addition to their own observations and experiences. First 30 writings or explanations of the importance of HRM and its learning which are in 30 well-known textbooks were examined. Then 13 common reasons were identified. Finally those 13 common reasons were arranged in the order of importance based on the intensity of consideration which refers to the number of counts for each reason in the writings or explanations.

\section{Reasons about the Importance of HRM and its Learning}

French (1978) believes in the two imperatives in modern organizations: (1) enhancing the quality of organizational life in a psychological and sociological sense; and (2) increasing organizational, group, and personal effectiveness. By the term effectiveness he includes such matters as productivity, efficiency, creativity, and vitality. According to him, these two imperatives can be opposite, complementary, or highly reinforcing, and as a matter of fact, the pressures to accommodate both are increasing, and it is vital that contemporary organizations find ways to enhance them. He further ascertains that one clear implication is: there is a growing need for all organizational members (managers, professionals, team leaders, and team members) to know more about and be more skilled in the 'people' aspects of management and organization so that the two imperatives are channeled in the way that is optimally synergetic.

One of the classic authors in HRM (then Personnel Management) is William F. Glueck. He (1979) stresses that personnel management (the term he used for HRM-this HRM term he had used as an alternative term to personnel management or personnel) contributes in many ways to ensure that the enterprise will survive and prosper. He mentions (p.8) that contributions personnel makes to organizational effectiveness are reflected in the objectives pursued by personnel specialists and departments, and these include:

1. To help the enterprise reach its goals.

2. To use the work force efficiently. 
3. To provide the enterprise with well-trained and well-motivated employees.

4. To increase to the fullest the employee's job satisfaction and self-actualization.

5. To develop and maintain a quality of work life which makes employment in the enterprise a desirable personal and social situation.

6. To communicate personnel and managerial policies to all concerned.

7. To help maintain ethical policies and behavior.

8. To manage change to the mutual advantage of individuals, groups, the enterprise, and the public.

These objectives indicate the importance of HRM and without HRM it is very difficult to achieve survival and prosperity of the enterprise.

Chruden and Sherman (1980) state in the preface of their textbook titled Personnel Management: The Utilization of Human Resources that effective utilization of personnel is essential to the well-being of individual employees and to the organizations that employ them. Also they state that hopefully, the skillful merging of human talents, needs, and aspirations with the requirements of organizations will result in overall benefits to society. Hence HRM is not only beneficial to the organizations where it is practiced, but also to employees working in those organizations and generally society.

Stone and Meltz (1983) wrote a textbook on Personnel Management in Canada and they did not mention in it specifically the importance of HRM or need for learning HRM. However it was indicted that personnel management (policies and programs that make effective use of the human resources of the organization) is the key to accomplishing management objectives such as survival of the organization, growth of the organization, and satisfactory levels of profit, production, and service. Also Beach (1985) in his book titled The Management of People at Work did not specify the need of HRM as a separate sub topic or unit of learning. He observed that people are truly the most precious resource of any company, and constructive and sound management of an enterprise's human resources is crucial to effective organizational performance. Further he writes that if management neglects this responsibility (managing people at work) the enterprise may founder. It is possible for the organization to fail because of nonexistence of constructive and sound HRM.

Schuler and Youngblood (1986) wrote a comprehensive textbook titled Effective Personnel Management. According to the both authors, good personnel management will contribute to the organization's bottom line by designing and implementing activities that provide the right number and kind of people at the right time for the organization. Further they write that personnel management can serve strategic purposes for the organization by increasing employee productivity, improving quality of work life, and complying with the myriads of laws that influence the management of human resources in today's organization. Personnel management will continue to be an important function in companies because it is more than a set of activities; it is a philosophy as well as a general belief that people are the most important resource in any organization. They furthermore observed that successful organizations rely on successful "people systems", and personnel management has much to 
offer the organizations of tomorrow. Answering the question "why is effective personnel management important to you?" they assert that effective personnel management can help the reader become a better manager and a more effective supervisor of others, regardless of where reader eventually works.

Heneman III, Schwab, Fossum, and Dyer (1989), in their book tilted Personnel/Human Resource Management, stated that P/HRM is aimed at influencing the effectiveness of employees in the organization. They modeled that HRM activities such as support ones (analyzing individuals and jobs, assessing outcomes, and human resource planning) and functional ones (external staffing, internal staffing and development, compensation, labor relations and work environment) attempt to influence several outcomes which are called personnel/human resource outcomes which include attraction, performance, retention, attendance, satisfaction, and others such as employee physical and mental well-being, accidents, and stress. Thus, according to them HRM is concerned with enhancing the contributions of employees toward the effectiveness of the organization.

Bernardin and Russell (1993) wrote a textbook titled Human Resource Management: An Experiential Approach that gives a comprehensive description and explanation of trends related to the increased importance of HRM. They gave a number of reasons for the increased attention being given to HRM by senior-level management. The reasons are (Bernardin and Russell, 1993):

1. The U.S. Productivity Crisis: One of the most popular theories to explain the productivity decline is the failure to recognize the role of people in the productivity ratio. The business world and management have been preoccupied with short-term variables such as return on investment, cost per unit, and earnings per share without weighing the role of workers and their potentiality for improving productivity. This failure to perceive a strong connection between the "human dimension" and productivity is changing, albeit slowly.

2. The increased importance being placed on HRM is the weight given to HRM activities in the process of evaluating companies for quality products and service. Many of the criteria for the Deming Award, a prestigious recognition of quality improvement presented in Japan annually since 1951 and named after W. Edwards Deming, an American consultant to industry, focus on HRM activities directed at quality improvement. Florida Power \& Light was the first U.S. company to be given the Deming Award, and the company stressed employee involvement and performance management systems as critical to its quality improvement. Another award called The Malcolm Baldrige (this name is the name of a man who served as Secretary of Commerce and his managerial excellence contributed to long-term improvement in efficiency and effectiveness of US government) National Quality Awards, U.S. presidential citations given to companies that show the greatest progress in improving the quality of their products, service, and customer satisfaction, also places substantial weight on the role of HRM in achieving quality and customer satisfaction. 
3. HRM policies and practices can create and sustain a competitive advantage. Research has shown that results of HRM programs which are measured in terms of criteria such as individual performance, employee absenteeism, turnover, accidents, aberrant employee behaviour (theft or substance abuse) can be directly linked to substantial cost savings, financial performance, and increased productivity.

4. Increasing international competition and the expanding global economy.

5. Increased government regulation and litigation: the proliferation of lawsuits and laws related to personnel decisions and policy resulted in the increased importance given to HRM by senior management.

6. Changing characteristics of the workforce: more educated employees make more demanding needs for innovative programs in training, compensation, performance management, and career development. Employees' attitudes are changing and they demand coordination between lifestyle needs (family, leisure) and employment needs necessitating different HRM methods. Diversity of workers, labor shortages and aging of the workforce, and job skills gap are other concerns which increase the importance of HRM.

Bratton and Gold (1994) who are UK academics did not particularly discuss the need of learning HRM in the book titled Human Resource Management: Theory and Practice. However, they presented a combined model of situational factors, stakeholder interests, and HR strategies. According to the combined model there are two types of HR objectives, i.e. HR effectiveness and organizational effectiveness. By using the Guest model of HRM, it seemed that they considered HRM outcomes as HR effectiveness and organizational outcomes as organizational effectiveness. Strategic integration, commitment, flexibility or adaptability, and quality under HR outcomes while high job performance; high problem solving, change, innovation; high cost-effectiveness, and low turnover, absence, and grievances under organizational outcomes.

Mamoria (1996) who is an Indian academic wrote a textbook titled Personnel Management and discussed the importance of HRM by citing the three standpoints proposed by Yodder, Heneman, Turnbull, and Stone. Three standpoints are social significance, professional significance, and significance for individual enterprise. HRM enhances employees' dignity by satisfying their social needs. HRM provides a healthy working environment for professional development of employees. HRM helps the organization accomplish its goals.

Werther and Davis (1996) in their textbook titled Human Resources and Personnel Management presented four objectives of HRM, i.e. organizational objective (to recognize that HRM exists to contribute to organizational effectiveness), functional objective (to maintain the HR department's contribution as a level appropriate to the organization's need), societal objective (to be ethically and socially responsive to the needs and challenges of society while minimizing the negative impact of such demands on the organization), and personal objective (to assist employees in achieving their personal goals, at least insofar as those goals enhance the individual's contribution to the organization). Thus there are multiple objectives to be achieved in HRM. According to the authors these multiple 
objectives become conflicting sometimes, hence they must be met, but only in a way that is appropriate to the organization being served.

Managing Human Resources is the title of the textbook written by three authors namely Bohlander, Snell, and Sherman (12 $2^{\text {th }}$ edition in 2001). The textbook that is recognized as the leader in introductory textbooks or the standard in the field of HRM according to the management and editors of South-Western College Publishing/Thomson Learning presents a separate section for the issue of "why study HRM?". Staffing the organization, designing jobs and teams, developing skillful employees, identifying approaches for improving their performance, and rewarding employee success-all typically labeled HRM issues- are as relevant to line managers as they are to managers in the HR department (Bohlander, Snell, and Sherman, 2001). The terms 'human resources', 'human capital', and 'intellectual assets' have in common the idea that people make the difference in how an organization performs; and while people have always been central to organizations, today they have taken on an even more central role in building a firm's competitive advantage according to them. Furthermore they stress that organizations can achieve competitive advantage through people if they are able to meet the following criteria:

1. The resources must be of value.

2. The resources must be rare.

3. The resources must be difficult to imitate.

4. The resources must be organized.

Kleiman (2004) wrote a textbook titled Human Resource Management: A Managerial Tool for Competitive Advantage presenting an original model to describe and explain how HRM contributes to organizational success by creating and enhancing a competitive advantage that is sustainable. According to the model, HRM practices result in employee-centered outcomes such as competence, motivation, and work-related attitudes (job satisfaction, organizational commitment, and organizational citizenship) which will subsequently result in organization-centered outcomes such as output, retention, legal compliance, and company image which finally contribute to create and enhance competitive advantage (cost leadership and product differentiation). This is the indirect path to HRM-competitive advantage linkage and there is direct path too, i.e. HRM practices impact on competitive advantage according to Kleiman (2004).

Fisher, Schoenfeldt, and Shaw (2006) in their textbook titled Human Resource Management discuss the critical importance of human resources in the twenty-first century. They observe that hardly a day goes by when organizational and $\mathrm{HR}$ issues are not in the news. According to them, the goal of HRM is to support organizations in gaining a competitive advantage, and physical resources, financial resources, marketing capability, and human resources are important to organizational effectiveness, but the factor most likely to provide potential competitive advantage is human resources and how these resources are managed. Furthermore they write that production technology, financing, and customer connections (marketing) can all be copied; and the basics of managing people can also be copied, but the 
unique ways of attracting, retaining, and motivating employees is a strategy that is more difficult to imitate.

Beardwell and Claydon (2007) did presenting a contemporary approach to HRM in the book titled Human Resource Management. Their work was an edited one and did not have a special topic or subtopic on the importance of HRM or need of learning HRM. One summarized point made by them is that the emergence of HRM and the emphasis on its contribution to the achievement of business goals has been perceived by many practitioners as an opportunity to improve power and status of the HR function. They discussed the model of HRM by Paauwe and Richardson according to which HRM activities (such as recruitment, selection, HR planning, rewards etc) lead to HRM outcomes (such as employee satisfaction, employee motivation, employee retention, employee presence, social climate between workers and management, trust, and commitment) which lead to performance (such as profit, market value, market share, increase in sales, productivity, product/service quality, customer satisfaction, development of products/services, and future investments).

Noe, Hollenbeck, Gerhart, and Wright (2007) conclude that HRM is critical to the success of organizations because human capital has certain qualities that make it valuable. They defined human capital as an organization's employees, described in terms of their training, experience, judgment, intelligence, relationships, and insight. These are the employee characteristics that can add economic value to the organization. In their book titled Fundamentals of Human Resource Management, it was explained that by influencing who works for the organization (type of human capital) and how those people work (behavior of human capital that includes motivation and effort), HRM contributes to such basic measures of an organization's success as quality, profitability, and customer satisfaction. Noe et al (2007) mention that human resources have four necessary qualities by which an organization can succeed through a sustainable competitive advantage, and these necessary qualities are: human resources are valuable, rare, cannot be imitated, and have no good substitutes. Furthermore, they concluded that these qualities imply that human resources have enormous potential.

Byars and Rue (2008) observed that human resource program reduces employee turnover and improves revenues. In their book titled Human Resource Management they showed many ways how human resource managers can have a direct impact on organizational performance. Some of them include reducing unnecessary overtime expenses by increasing productivity, instituting programs to reduce absenteeism, eliminating wasted time through sound job design, minimizing employee turnovers and unemployment costs by practicing sound human relations and creating a work atmosphere that promotes job satisfaction, etc.

DeNisi and Griffin (2008) present four basic goals of the HRM function in most organizations today in their book titled Human Resource Management. They include facilitating organizational competitiveness, complying with legal and social obligations, enhancing productivity and quality, and promoting growth and development. They believe that facilitating organizational competitiveness must be the most important goal for modern 
HRM because it is the goal that sets the modern function apart even from the HRM function of twenty years ago, and it is the way in which the HRM function provides the most value to the organization.

Opatha (2009), the author of this research paper being a Sri Lankan academic, wrote a comprehensive textbook tilted Human Resource Management: Personnel which was the first textbook in English medium published in Sri Lanka (only one to date). In the textbook there is a separate section or sub topic called Importance of HRM which presents five reasons of why HRM is of very importance for an organization. They are:

1. Human resources are the most important resource that managers utilize to achieve goals of an organization.

2. Quality of other functional fields of management heavily depends on quality of HRM in an organization.

3. HRM is a vital responsibility of every manager in an organization.

4. HRM contributes to organizational success and then societal success.

5. Management of employees is more difficult than managing other resources.

Cascio (2010) asserts that the enterprise is the people. In their textbook titled Managing Human Resources it was stressed that organizations are managed and staffed by people and without them, organizations cannot exist. According to him, indeed, the challenge, the opportunity, and also the frustration of creating and managing organizations frequently stem from the people-related problems that arise within them. He points out that managing people is a critical role for every manager, and shows a strong connection between how firms manage their people and the economic results they achieve by presenting research evidence. The use of best practices (high-performance work practices) such as staffing, job design, information sharing, performance appraisal, promotion systems, attitude assessment, incentive systems, grievance procedures, and labor-management participation was found to have superior financial performance (Cascio, 2010).

Gomez-Mejia, Balkin, and Cardy (2010) preface that the unprecedented economic upheavals on a global basis since 2008 have made it even clearer that all managers should be able to deal effectively with many HR issues. These issues include preparing labor reduction plans; identifying key employees that the firm must keep despite declining profits; managing rising stress, anxiety, and depression; rewarding individuals for achieving important milestones; inducing employers to take prudent risks within their purview of responsibilities; crosstraining employees so that they are capable of fulfilling different job roles; enabling employees to become culturally savvy so that they can relate to diverse audiences both domestically and internationally; and treating employees in an ethical way.

Ivancevich (2010) in the book titled Human resource Management summarizes that HRM focuses on satisfying the needs of individuals at work; it is a necessary function, and effectively performed, it can make the crucial difference between successful and unsuccessful organizations; every manager is involved, in some way, with it; and it is one of 
the most challenging and exciting functions in an organization. Further he states that HRM activities play a major role in ensuring that an organization will survive or prosper; HRM contributes to organizational effectiveness in terms of criteria such as performance, legal compliance, employee satisfaction, absenteeism, turnover, training effectiveness and return on investment, grievance rates, and accident rates; and employees limit or enhance the strengths and weaknesses of an organization.

Mathis and Jackson (2011) in their textbook titled Human Resource Management emphasize that Human resources are a core competency because it differentiates an organization from its competitors and is a key determinant of competitive advantages. According to them, contributions by HRM can include improving productivity, meeting social responsibilities, enhancing customer service and quality, and expanding employee engagement.

Torrington, Hall, Taylor, and Atkinson (2011) are British academics who wrote a comprehensive textbook on HRM. In the book titled Human Resource Management it was summarized that the HRM function contributes to the achievement of different dimensions of organizational effectiveness such as the gaining and maintaining of competitive advantage, the fostering of a positive standing in financial markets and the development of a reputation for corporate social responsibility.

Human resources are the most important resource because of its unique characteristics which include that it is animate, active and living; it has the ability to think, feel and react; its value gets appreciated with the passage of time (owing experience, training, and education); it has the ability to influence on determining its cost (pay); it has the ability to organize (as unions, teams etc.); its behaviour is complex and may be unpredictable; it has the ability of creativity and innovation, which cannot be found in any other resource; and it makes decisions in respect of all other resources (Opatha, 1995; Opatha, 2009).

According to Jackson, Schuler, and Werner (2012), managing human resources is critical to the success of all companies, large and small, regardless of industry, and also it is possible for companies to gain and sustain a competitive advantage over other companies by managing their people in ways that add value to the organization but are difficult for other companies to duplicate. By using empirical evidence, they mentioned in their preface that managers from the very largest multinational firms to the smallest domestic companies claim that managing people effectively is vital to success in today's highly competitive market place: "the relationship we have with our people and culture of our company is our most sustainable competitive advantage" and in a service business like ours, all roads to success have always led back to the human side of the business".

Lussier and Hendon (2013) in their textbook titled Human Resource Management: Functions, Applications, Skill Development discuss "why study HRM?" as a separate sub topic. They (2013, p. 4) write: 
"It's natural at this point to be thinking, "What can I get from this book?" or "What's in it for me?" These questions are seldom asked or answered directly. But they should be answered. Success in our professional and personal lives is about creating relationships, and students understand the importance of relationships. So the short answer is that the better you can work with people-and this is what most of this book is about-the more successful you will be in your personal and professional lives as an employee, a manager, or a Human Resource Manager."

Thus, studying HRM is needed because the learner has to be successful in his or her personal and professional lives as an employee, a manager, or a Human Resource Manager. Furthermore they explain that managers, particularly HR managers need to be strategic, business focused, customer focused, and generally in tune with the overall operational success of the organization, and hence they have been forced to think in more strategic terms about how their organization can win against their competitors by utilizing their human resources.

Armstrong and Taylor (2014) who are British authors wrote a very comprehensive textbook and according to its latest edition, there are several goals of HRM which indicate the importance of HRM although the need for learning HRM is not discussed specially. Goals of HRM are to: support the organization in achieving its objective by developing and implementing HR strategies, that are integrated with business strategy; contribute to the development of a high-performance culture; ensure that the organization has the talented, skilled and engaged people it needs; create a positive employment relationship between management and employees and a climate of trust; and encourage the application of an ethical approach to people management.

Stewart and Brown (2014) wrote a unique textbook on HRM with a focus on linking strategy to practice. In their book they did not exclusively discuss the need of learning HRM. Anyway they discussed the contribution of HRM to success through the use of an organization's life cycle. They (p. 30) summarize:

"In the entrepreneurial stage, survival equals success. Human resource management helps the organization find employees. Success during the communal stage is marked by expansion and innovation. Building a sense of belonging and satisfying the needs of employees are critical. During the formalization stage, success comes from developing clear and efficient procedures. Human resource management builds structured programs that provide consistent procedures. An organization must change and adapt in the elaboration stage. This change is facilitated by hiring and rewarding people who have new ideas and different ways of doing things."

Furthermore they explained the importance of HRM through the use of stakeholder perspective that focuses on people who affect and are affected by an organization. Good HRM practices protect the interests of employees who become satisfied and skilled enabling them to meet effectively the needs of customers. Organizations with more effective HRM 
practices have higher profits. Better HRM can contribute to society as a whole by protecting the environment and helping disadvantaged people.

Bohlander and Snell (2017) in their textbook titled Principles of Human Resource Management discussed separately why HRM is studied. Learning HRM is critical for a person who wants to be a HR professional. Also they stress that having a good understanding of HRM is important for managers and entrepreneurs of all types as they are responsible for at least some of the activities which fall into the category of HRM. A poor job of HRM will lead to failures of businesses. Believe it or not, many business people with great business strategies, business plans, and products and services fail because they do not fully grasp the importance of HRM (Bohlander and Snell, 2017). They write, in addition, great business plans and products and services can easily be copied by one's competitors, but great personnel cannot. Employees' knowledge and abilities are among the most distinctive and renewable resources upon which a company can draw.

Opatha (2019) wrote an innovative textbook on HRM titled Sustainable Human Resource Management which expanded horizons of HRM. Sustainability is the issue that has to be dealt with all people in the society now and in future. It is the deliberate constant endeavour to utilize human and other resources, and natural environment to meet needs of current stakeholders of the organization while maintaining and if possible enhancing human and other resources, and natural environment to meet needs of future stakeholders (Opatha, 2019). According to him, a careful examination of various sustainability issues and practices reveals that HRM plays and will have to play a critical role in making an organization sustainable. Opatha (2019, p. 35) summarizes:

"Integration of sustainability into HRM results in creating a new branch called Sustainable HRM which is that part of Human Resource Management which is concerned with Planet-related matters, Society-related matters and Profit-related matters. Its aim is to maximize environmental, social, and economic performance of the organization. Based on the concept of the TBL, De Prins' Model of Sustainable HRM, and the logical beliefs of the author, it is perceived clearly that sustainable HRM has three dimensions, i.e. planet-related, people-related and profit-related which are labeled as Green HRM, Social HRM and Economic HRM respectively."

Thus, HRM is important as it can contribute significantly to enhance environmental, social, and economic performance of the organization. Specifically HRM can make normal employees green to contribute to preservation, conservation, non-pollution, and making looking like natural places; can enhance adherence to organizational ethics, work-family balance, quality of work life, health and safety, and happiness of employees in the organization; and can enhance high performance organization, employee retention, customer satisfaction, avoiding and minimizing absenteeism and presenteeism, and matching competitive business strategy and HR strategy.

Exhibit 1 presents the writings (explanations) given above by various scholars with regard to the importance of HRM and its learning. 
Exhibit: 1 Writings of the Importance of HRM and Its Learning

\begin{tabular}{|c|c|c|c|}
\hline Number & Writings (Explanation) & Author/Authors & Year \\
\hline 1 & $\begin{array}{l}\text { A growing need for all organizational members to } \\
\text { know about and be more skilled in the 'people' aspects } \\
\text { of management and organization in order to channel } \\
\text { the two imperatives- (1) enhancement of quality of } \\
\text { organizational life in a psychological and sociological } \\
\text { sense; and (2) increase of organizational, group, and } \\
\text { personal effectiveness-in an optimally synergetic way }\end{array}$ & French & 1978 \\
\hline 2 & $\begin{array}{l}\text { Following objectives indicate the importance of HRM } \\
\text { and without HRM it is very difficult to achieve survival } \\
\text { and prosperity of the enterprise. } \\
\text { 1. To help the enterprise reach its goals. } \\
\text { 2. To use the work force efficiently. } \\
\text { 3. To provide the enterprise with well-trained and } \\
\text { well-motivated employees. } \\
\text { 4. To increase to the fullest the employee's job } \\
\text { satisfaction and self-actualization. } \\
\text { 5. To develop and maintain a quality of work life } \\
\text { which makes employment in the enterprise a } \\
\text { desirable personal and social situation. } \\
\text { 6. To communicate personnel and managerial } \\
\text { policies to all concerned. } \\
\text { 7. To help maintain ethical policies and behavior. } \\
\text { 8. To manage change to the mutual advantage of } \\
\text { individuals, groups, the enterprise, and the } \\
\text { public. }\end{array}$ & Glueck & 1979 \\
\hline 3 & $\begin{array}{l}\text { Effective utilization of personnel is essential to the } \\
\text { well-being of individual employees and to the } \\
\text { organizations that employ them; and the skillful } \\
\text { merging of human talents, needs, and aspirations with } \\
\text { the requirements of organizations will result in overall } \\
\text { benefits to society. }\end{array}$ & $\begin{array}{l}\text { Chruden and } \\
\text { Sherman }\end{array}$ & 1980 \\
\hline 4 & $\begin{array}{l}\text { Personnel management is the key to accomplishing } \\
\text { management objectives such as survival of the } \\
\text { organization, growth of the organization, and } \\
\text { satisfactory levels of profit, production, and service. }\end{array}$ & Stone and Meltz & 1983 \\
\hline 5 & $\begin{array}{l}\text { People are truly the most precious resource of any } \\
\text { company, and constructive and sound management of } \\
\text { an enterprise's human resources is crucial to effective } \\
\text { organizational performance. }\end{array}$ & Beach & 1985 \\
\hline 6 & $\begin{array}{l}\text { Good personnel management will contribute to the } \\
\text { organization's bottom line by designing and }\end{array}$ & $\begin{array}{l}\text { Schuler and } \\
\text { Youngblood }\end{array}$ & 1986 \\
\hline
\end{tabular}




\begin{tabular}{|c|c|c|c|}
\hline & $\begin{array}{l}\text { implementing activities that provide the right number } \\
\text { and kind of people at the right time for the } \\
\text { organization. It can serve strategic purposes for the } \\
\text { organization by increasing employee productivity, } \\
\text { improving quality of work life, and complying with the } \\
\text { myriads of laws that influence the management of } \\
\text { human resources in today's organization. It will } \\
\text { continue to be an important function in companies } \\
\text { because it is more than a set of activities; it is a } \\
\text { philosophy as well as a general belief that people are } \\
\text { the most important resource in any organization. } \\
\text { Effective personnel management can help the reader } \\
\text { become a better manager and a more effective } \\
\text { supervisor of others, regardless of where reader } \\
\text { eventually works. }\end{array}$ & & \\
\hline 7 & $\begin{array}{l}\text { P/HRM is aimed at influencing the effectiveness of } \\
\text { employees in the organization. It enhances the } \\
\text { contributions of employees toward the effectiveness } \\
\text { of the organization. }\end{array}$ & $\begin{array}{l}\text { Heneman III, } \\
\text { Schwab, Fossum, } \\
\text { and Dyer }\end{array}$ & 1989 \\
\hline 8 & $\begin{array}{l}\text { Increased attention being given to HRM by senior } \\
\text { management is due to the reasons: the U.S. } \\
\text { productivity crisis, the weight given to HRM activities } \\
\text { in the process of evaluating companies for quality } \\
\text { products and services, competitive advantage created } \\
\text { and sustained by HRM policies and practices, } \\
\text { increasing international competition and the } \\
\text { expanding global economy, increased government } \\
\text { regulation and litigation, and changing characteristics } \\
\text { of the workforce }\end{array}$ & $\begin{array}{l}\text { Bernarding and } \\
\text { Russell }\end{array}$ & 1993 \\
\hline 9 & $\begin{array}{l}\text { HR effectiveness which refers to HR outcomes which } \\
\text { include strategic integration, commitment, flexibility or } \\
\text { adaptability, and quality. Organizational effectiveness } \\
\text { which refers to organizational outcomes which include } \\
\text { high job performance; high problem solving, change, } \\
\text { innovation; high cost-effectiveness, and low turnover, } \\
\text { absence, and grievances. }\end{array}$ & Bratton and Gold & 1994 \\
\hline 10 & $\begin{array}{l}\text { Three standpoints are social significance, professional } \\
\text { significance, and significance for individual enterprise. } \\
\text { HRM enhances employees' dignity by satisfying their } \\
\text { social needs. HRM provides a healthy working } \\
\text { environment for professional development of } \\
\text { employees. HRM helps the organization accomplish its } \\
\text { goals. }\end{array}$ & Mamoria & 1996 \\
\hline
\end{tabular}




\begin{tabular}{|c|c|c|c|}
\hline 11 & $\begin{array}{l}\text { Four objectives of HRM, i.e. organizational objective } \\
\text { (to recognize that HRM exists to contribute to } \\
\text { organizational effectiveness), functional objective (to } \\
\text { maintain the HR department's contribution as a level } \\
\text { appropriate to the organization's need), societal } \\
\text { objective (to be ethically and socially responsive to the } \\
\text { needs and challenges of society while minimizing the } \\
\text { negative impact of such demands on the organization), } \\
\text { and personal objective (to assist employees in } \\
\text { achieving their personal goals, at least insofar as those } \\
\text { goals enhance the individual's contribution to the } \\
\text { organization). }\end{array}$ & $\begin{array}{l}\text { Werther and } \\
\text { Davis }\end{array}$ & 1996 \\
\hline 12 & $\begin{array}{l}\text { HRM issues such as staffing the organization, } \\
\text { designing jobs and teams, developing skillful } \\
\text { employees, identifying approaches for improving their } \\
\text { performance, and rewarding employee success are as } \\
\text { relevant to line managers as they are to managers in } \\
\text { the HR department. People make the difference in } \\
\text { how an organization performs. While people have } \\
\text { always been central to organizations, today they have } \\
\text { taken on an even more central role in building a firm's } \\
\text { competitive advantage. }\end{array}$ & $\begin{array}{l}\text { Bohlander, Snell, } \\
\text { and Sherman }\end{array}$ & 2001 \\
\hline 13 & $\begin{array}{l}\text { HRM contributes to organizational success by creating } \\
\text { and enhancing a competitive advantage that is } \\
\text { sustainable in a direct way as well as an indirect way } \\
\text { through employee-centered outcomes such as } \\
\text { competence, motivation, and work-related attitudes } \\
\text { (job satisfaction, organizational commitment, and } \\
\text { organizational citizenship); then organization-centered } \\
\text { outcomes such as output, retention, legal compliance, } \\
\text { and company image. }\end{array}$ & Kleiman & 2004 \\
\hline 14 & $\begin{array}{l}\text { The goal of HRM is to support organizations in gaining } \\
\text { a competitive advantage, and the factor most likely to } \\
\text { provide potential competitive advantage is human } \\
\text { resources and how these resources are managed. }\end{array}$ & $\begin{array}{l}\text { Fisher, } \\
\text { Schoenfeldt, and } \\
\text { Shaw }\end{array}$ & 2006 \\
\hline 15 & $\begin{array}{l}\text { The emergence of HRM and the emphasis on its } \\
\text { contribution to the achievement of business goals has } \\
\text { been perceived by many practitioners as an } \\
\text { opportunity to improve power and status of the HR } \\
\text { function. HRM activities lead to HRM outcomes (such } \\
\text { as employee satisfaction, employee motivation, } \\
\text { employee retention, employee presence, social climate } \\
\text { between workers and management, trust, and } \\
\text { commitment) which lead to performance (such as }\end{array}$ & $\begin{array}{l}\text { Beardwell and } \\
\text { Claydon }\end{array}$ & 2007 \\
\hline
\end{tabular}




\begin{tabular}{|c|c|c|c|}
\hline & $\begin{array}{l}\text { profit, market value, market share, increase in sales, } \\
\text { productivity, product/service quality, customer } \\
\text { satisfaction, development of products/services, and } \\
\text { future investments). }\end{array}$ & & \\
\hline 16 & $\begin{array}{l}\text { HRM is critical to the success of organizations because } \\
\text { human capital has certain qualities that make it } \\
\text { valuable. Employee characteristics such as their } \\
\text { training, experience, judgment, intelligence, } \\
\text { relationships, and insight can add economic value to } \\
\text { the organization. Human resources have four } \\
\text { necessary qualities by which an organization can } \\
\text { succeed through a sustainable competitive advantage, } \\
\text { and these necessary qualities are: human resources are } \\
\text { valuable, rare, cannot be imitated, and have no good } \\
\text { substitutes. }\end{array}$ & $\begin{array}{l}\text { Noe, Hollenbeck, } \\
\text { Gerhart, and } \\
\text { Wright }\end{array}$ & 2007 \\
\hline 17 & $\begin{array}{l}\text { Human resource program reduces employee turnover } \\
\text { and improves revenues. In many ways human resource } \\
\text { managers can have a direct impact on organizational } \\
\text { performance. }\end{array}$ & Byars and Rue & 2008 \\
\hline 18 & $\begin{array}{l}\text { Four basic goals of the HRM: facilitating organizational } \\
\text { competitiveness, complying with legal and social } \\
\text { obligations, enhancing productivity and quality, and } \\
\text { promoting growth and development. }\end{array}$ & DeNisi and Griffin & 2008 \\
\hline 19 & $\begin{array}{l}\text { Five reasons of why HRM is of very importance for an } \\
\text { organization: } \\
\text { 1. Human resources are the most important } \\
\text { resource that managers utilize to achieve goals } \\
\text { of an organization. } \\
\text { 2. Quality of other functional fields of } \\
\text { management heavily depends on quality of } \\
\text { HRM in an organization. } \\
\text { 3. HRM is a vital responsibility of every manager in } \\
\text { an organization. } \\
\text { 4. HRM contributes to organizational success and } \\
\text { then societal success. } \\
\text { 5. Management of employees is more difficult } \\
\text { than managing other resources. }\end{array}$ & Opatha & 2009 \\
\hline 20 & $\begin{array}{l}\text { Organizations are managed and staffed by people and } \\
\text { without them, organizations cannot exist. The } \\
\text { challenge, the opportunity, and also the frustration of } \\
\text { creating and managing organizations frequently stem } \\
\text { from the people-related problems that arise within }\end{array}$ & Cascio & 2010 \\
\hline
\end{tabular}




\begin{tabular}{|c|c|c|c|}
\hline & $\begin{array}{l}\text { them. Managing people is a critical role for every } \\
\text { manager. The use of best practices (high-performance } \\
\text { work practices) was found to have superior financial } \\
\text { performance. }\end{array}$ & & \\
\hline 21 & $\begin{array}{l}\text { All managers should be able to deal effectively with } \\
\text { many HR issues. }\end{array}$ & $\begin{array}{l}\text { Gomez-Mejia, } \\
\text { Balkin, and Cardy }\end{array}$ & 2010 \\
\hline 22 & $\begin{array}{l}\text { HRM focuses on satisfying the needs of individuals at } \\
\text { work; it can make the crucial difference between } \\
\text { successful and unsuccessful organizations; every } \\
\text { manager is involved, in some way, with it; and it is one } \\
\text { of the most challenging and exciting functions in an } \\
\text { organization. HRM activities play a major role in } \\
\text { ensuring that an organization will survive or prosper. }\end{array}$ & Ivancevich & 2010 \\
\hline 23 & $\begin{array}{l}\text { Human resources are a core competency because it } \\
\text { differentiates an organization from its competitors and } \\
\text { is a key determinant of competitive advantages. } \\
\text { Contributions by HRM can include improving } \\
\text { productivity, meeting social responsibilities, enhancing } \\
\text { customer service and quality, and expanding employee } \\
\text { engagement. }\end{array}$ & $\begin{array}{l}\text { Mathis and } \\
\text { Jackson }\end{array}$ & 2011 \\
\hline 24 & $\begin{array}{l}\text { The HRM function contributes to the achievement of } \\
\text { different dimensions of organizational effectiveness } \\
\text { such as the gaining and maintaining of competitive } \\
\text { advantage, the fostering of a positive standing in } \\
\text { financial markets and the development of a reputation } \\
\text { for corporate social responsibility. }\end{array}$ & $\begin{array}{l}\text { Torrington, Hall, } \\
\text { Taylor, and } \\
\text { Atkinson }\end{array}$ & 2011 \\
\hline 25 & $\begin{array}{l}\text { Managing human resources is critical to the success of } \\
\text { all companies, large and small, regardless of industry, } \\
\text { and also it is possible for companies to gain and sustain } \\
\text { a competitive advantage over other companies by } \\
\text { managing their people in ways that add value to the } \\
\text { organization but are difficult for other companies to } \\
\text { duplicate. }\end{array}$ & $\begin{array}{l}\text { Jackson, Schuler, } \\
\text { and Werner }\end{array}$ & 2012 \\
\hline 26 & $\begin{array}{l}\text { Studying HRM is needed because the learner has to be } \\
\text { successful in his or her personal and professional lives } \\
\text { as an employee, a manager, or a Human Resource } \\
\text { Manager. Managers, particularly HR managers need to } \\
\text { be strategic, business focused, customer focused, and } \\
\text { generally in tune with the overall operational success } \\
\text { of the organization, and hence they have been forced } \\
\text { to think in more strategic terms about how their } \\
\text { organization can win against their competitors by } \\
\text { utilizing their human resources. }\end{array}$ & $\begin{array}{l}\text { Lussier and } \\
\text { Hendon }\end{array}$ & 2013 \\
\hline
\end{tabular}




\begin{tabular}{|c|c|c|c|}
\hline 27 & $\begin{array}{l}\text { Goals of HRM are to: support the organization in } \\
\text { achieving its objective by developing and } \\
\text { implementing HR strategies, that are integrated with } \\
\text { business strategy; contribute to the development of a } \\
\text { high-performance culture; ensure that the organization } \\
\text { has the talented, skilled and engaged people it needs; } \\
\text { create a positive employment relationship between } \\
\text { management and employees and a climate of trust; } \\
\text { and encourage the application of an ethical approach } \\
\text { to people management. }\end{array}$ & $\begin{array}{l}\text { Armstrong and } \\
\text { Taylor }\end{array}$ & 2014 \\
\hline 28 & $\begin{array}{l}\text { The contributions of HRM to success occur throughout } \\
\text { the stages of an organization's life cycle. Good HRM } \\
\text { practices protect the interests of employees who } \\
\text { become satisfied and skilled enabling them to meet } \\
\text { effectively the needs of customers. Organizations with } \\
\text { more effective HRM practices have higher profits. } \\
\text { Better HRM can contribute to society as a whole by } \\
\text { protecting the environment and helping disadvantaged } \\
\text { people. }\end{array}$ & $\begin{array}{l}\text { Stewart and } \\
\text { Brown }\end{array}$ & 2014 \\
\hline 29 & $\begin{array}{l}\text { Learning HRM is critical for a person who wants to be a } \\
\text { HR professional. Having a good understanding of HRM } \\
\text { is important for managers and entrepreneurs of all } \\
\text { types as they are responsible for at least some of the } \\
\text { activities which fall into the category of HRM. }\end{array}$ & $\begin{array}{l}\text { Bohlander and } \\
\text { Snell }\end{array}$ & 2017 \\
\hline 30 & $\begin{array}{l}\text { HRM can significantly contribute to sustainability by } \\
\text { enhancing environmental, social, and economic } \\
\text { performance of the organization. Specifically HRM can } \\
\text { make normal employees green to contribute } \\
\text { significantly to preservation, conservation, non- } \\
\text { pollution, and making looking like natural places; can } \\
\text { enhance adherence to organizational ethics, work- } \\
\text { family balance, quality of work life, health and safety, } \\
\text { and happiness of employees in the organization; and } \\
\text { can enhance high performance organization, employee } \\
\text { retention, customer satisfaction, avoiding and } \\
\text { minimizing absenteeism and presenteeism, and } \\
\text { matching competitive business strategy and HR } \\
\text { strategy. }\end{array}$ & Opatha & 2019 \\
\hline
\end{tabular}

A careful examination of the above mentioned writings or explanations does reveal that there are some distinct reasons given by different authors. Some reasons, if not many, do exist justifying the need of teaching HRM in ME. 


\section{Included or Derived Reasons}

It was possible to make an attempt for the purpose of identifying some common reasons which are included directly in or derive from the writings or explanations considered under this study. In this study 30 writings done by more than thirty authors with regard to the need of learning HRM or the importance of HRM were considered and examined. Here 'common reason' refers to a ground or a justification that has been included in or can be derived from at least two or more writings. The attempt made to examine the writings resulted in identifying some common reasons which are listed below:

1. Organizational survival (to maintain the organization)

2. Organizational success (to accomplish organizational objectives such as profits, market share, productivity, etc)

3. Sustainable competitive advantage and organizational improvement (growth)

4. Enhancing quality of organizational life for employees

5. Enhancing personal life success

6. Enhancing professional life success

7. Uniqueness of human resources

8. Other functional fields' dependency

9. Every manager's vital responsibility

10. Contribution to societal success

11. Contribution to the natural environment

12. HRM profession's growth

13. Legal compliance (adhering to laws about managing people at work)

Thus, 13 reasons were identified as common reasons and they were considered for a content analysis which is in the section that follows. There are non-common reasons which can be considered as important reasons for the need of teaching HRM in ME and they are:

1. Productivity crisis

2. Increased importance given to HRM activities in the process of evaluating companies for quality products and services

3. Changing characteristics of the workforce

4. Management of employees is more difficult than managing other resources.

\section{Content Analysis of the Common Reasons}

Identified or derived common reasons for the need of teaching HRM in ME were 13. By using 13 items an attempt was done to find out the intensity of consideration. A working definition is a nominal definition assigned by the researcher to a term in order to accomplish his or her research objectives (Babbie, 1986; Opatha, 2003). The working definition assigned to the intensity of consideration is the number of counts for each reason in the writings of the authors of the textbooks. Based on the above reasons the contents of all the 30 writings or explanations of the importance of HRM and its learning were examined and the results of the content analysis are shown in Table 1. 
Table: 1 Reasons in the Writings or Explanations of the Importance of HRM and Its Leaning

\begin{tabular}{|c|c|c|c|c|c|c|c|c|c|c|c|c|c|}
\hline \multirow[t]{2}{*}{ Author/s } & \multicolumn{13}{|c|}{ Reasons } \\
\hline & 1 & 2 & 3 & 4 & 5 & 6 & 7 & 8 & 9 & 10 & 11 & 12 & 13 \\
\hline 1. French & & $x$ & & $x$ & & $x$ & & & & & & & \\
\hline 2. Glueck & $x$ & $x$ & & $x$ & $x$ & & & & & $x$ & & & \\
\hline 3. Chruden and Sherman & & $x$ & & & $x$ & & & & & $x$ & & & \\
\hline 4. Stone and Meltz & $x$ & $x$ & $x$ & & & & & & & & & & \\
\hline 5. Beach & & $x$ & & & & & $x$ & & & & & & \\
\hline 6. Schuler and Youngblood & & $x$ & & $x$ & & $x$ & $x$ & $x$ & $\times$ & & & & $\times$ \\
\hline $\begin{array}{l}\text { 7. Heneman III, Schwab, Fossum, } \\
\text { and Dyer }\end{array}$ & & $x$ & & & & $x$ & & & & & & & \\
\hline 8. Bernarding and Russell & & $x$ & $x$ & & & & & & & & & & $x$ \\
\hline 9. Bratton and Gold & & $x$ & & & & & & & & & & & \\
\hline 10. Mamoria & & $x$ & & & $x$ & $x$ & & & & $x$ & & & \\
\hline 11. Werther and Davis & & $x$ & & & $x$ & & & & & & & $x$ & \\
\hline 12. Bohlander, Snell, and Sherman & & & $x$ & & & & $x$ & & $x$ & & & & \\
\hline 13. Kleiman & & $x$ & $x$ & & & & & & & & & & \\
\hline 14. Fisher, Schoenfeldt, and Shaw & & & & & & & & & & & & & \\
\hline 15. Beardwell and Claydon & & $x$ & & & & & & & & & & $x$ & \\
\hline $\begin{array}{l}\text { 16. Noe, Hollenbeck, Gerhart, and } \\
\text { Wright }\end{array}$ & & & & & & & & & & & & & \\
\hline 17. Byars and Rue & & $x$ & & & & & & & & & & & \\
\hline 18. DeNisi and Griffin & & $x$ & $x$ & & & & & & & & & & $x$ \\
\hline 19. Opatha & & $x$ & & & & & $x$ & $x$ & $x$ & $\times$ & & & \\
\hline 20. Cascio & & $x$ & & & & & & $x$ & $x$ & & & & \\
\hline $\begin{array}{l}\text { 21. Gomez-Mejia, Balkin, and } \\
\text { Cardy }\end{array}$ & & & & & & & & & $x$ & & & & \\
\hline 22. Ivancevich & $x$ & $x$ & & & & $x$ & & & $x$ & & & & \\
\hline 23. Mathis and Jackson & & $x$ & $x$ & & & & & & & $x$ & $x$ & & \\
\hline $\begin{array}{l}\text { 24. Torrington, Hall, Taylor, and } \\
\text { Atkinson }\end{array}$ & & $x$ & $x$ & & & & & & & $x$ & $x$ & & \\
\hline 25. Jackson, Schuler, and Werner & & $x$ & $x$ & & & & & & & & & & \\
\hline 26. Lussier and Hendon & & & & & $x$ & $x$ & & & $x$ & & & & \\
\hline 27. Armstrong and Taylor & & $x$ & & $x$ & & & & & & & & & \\
\hline 28. Stewart and Brown & & $x$ & & & & & & & & $x$ & $x$ & & \\
\hline 29. Bohlander and Snell & & & & & & $x$ & & & $x$ & & & & \\
\hline 30. Opatha & & $x$ & $x$ & & $x$ & & & & & $x$ & $x$ & & \\
\hline Total & 03 & 24 & 09 & 04 & 06 & 07 & 04 & 03 & 08 & 08 & 04 & 02 & 03 \\
\hline
\end{tabular}

According to the results of content analysis of the writings or explanations which are 30 in number, out of 13 reasons the item that has the highest intensity of consideration (number of counts in the writings) is the item numbered 2, i.e. organizational success. The next highest item is the item numbered 3 , i.e. sustainable competitive advantage and 
organizational improvement. For the third place there are two items numbered 9 and 10 i.e. every manager's vital responsibility and contribution to societal success. The fourth one or place in terms of the intensity of consideration is the item numbered 6, i.e. enhancing professional life success. The fifth place is for the item numbered 5, i.e. enhancing personal life success. The common reasons can be arranged in terms of importance based on the intensity of consideration in the writings of the authors of the textbook and the arrangement is given in Table 2 (in the descending order):

Table: 2 Arrangement of 13 Common Reasons in the Order of Importance

\begin{tabular}{|l|l|l|}
\hline No. & Common Reason & Order \\
\hline 1 & Organizational survival (to maintain the organization) & 7 \\
\hline 2 & $\begin{array}{l}\text { Organizational success (to accomplish organizational objectives such as } \\
\text { profits, market share, productivity, etc) }\end{array}$ & 1 \\
\hline 3 & $\begin{array}{l}\text { Sustainable competitive advantage and organizational improvement } \\
\text { (growth) }\end{array}$ & 2 \\
\hline 4 & Enhancing quality of organizational life for employees & 6 \\
\hline 5 & Enhancing personal life success & 5 \\
\hline 6 & Enhancing professional life success & 4 \\
\hline 7 & Uniqueness of human resources & 6 \\
\hline 8 & Other functional fields' dependency & 7 \\
\hline 9 & Every manager's vital responsibility & 3 \\
\hline 10 & Contribution to societal success & 3 \\
\hline 11 & Contribution to the natural environment & 6 \\
\hline 12 & HRM profession's growth & 8 \\
\hline 13 & Legal compliance (adhering to laws about managing people at work) & 7 \\
\hline
\end{tabular}

\section{Discussion and Conclusion}

This research paper is not a traditional one using generally accepted research methods. Being a conceptual paper this paper was written to fill a gap in the theoretical knowledge about reasoning the need of learning $\mathrm{HRM}$ in $\mathrm{ME}$ in terms of having a synthesized description of reasoning and presenting a set of reasons to explain the need, and in addition, to solve an intellectual puzzle to uncover why HRM is to be taught in any qualification of Management at any level. Three research questions were formulated to be answered systematically, and the first one was "What are the arguments or reasons for the case for teaching HRM in Management Education which can be discovered from the existent literature?". The finding of the examination of relevant writings given in 30 well-known textbooks reveals that there are at least 17 reasons. It should be noted that direct writings or explanation about why HRM needs to be taught or learnt could be found only in three textbooks (Bohlander, Sneel, and Sherman, 2001; Lussier and Hendon, 2013; Bohlander and Snell, 2017). Only six textbooks (Schuler and Youngblood, 1986; Bernardin and Russell, 1993; Mamoria, 1996; Fisher, Schoenfeldt, and Shaw, 2006; Opatha, 2009; Opatha, 2019) had a separate section or sub topic on the importance of HRM. Although the rest of the textbooks 
did not have a separate sub topic on the importance of HRM they discussed the contributions and impacts made by HRM and objectives of HRM.

The second research question of this study was "Are there common reasons which necessitate teaching HRM in Management Education?". The finding of the attempt made to identify some common reasons which are included directly or derive from the writings in the 30 textbooks was that 13 common reasons or arguments exist. The third research questions was "Can the common reasons be arranged in terms of importance?". Based on the intensity of consideration it was found that only 8 ranks could be given owing to the fact that some reasons got the same intensity. The arrangement in terms of the order of importance reveals that the most importance reason or argument for the case for learning HRM in ME is organizational success. It was well established theoretically and empirically that HRM does contribute significantly to accomplish organizational objectives such as profits, market share, productivity, employee retention, product or service quality, customer satisfaction etc. Top reasons include $\left(2^{\text {nd }}\right.$ rank) sustainable competitive advantage and organizational improvement, ( $3^{\text {rd }}$ rank) every manager's vital responsibility and contribution to societal success (these two reasons got the same intensity of consideration being the top third reason), ( $4^{\text {th }}$ rank) enhancing professional life success, and ( $5^{\text {th }}$ rank) enhancing personal life success.

From the point of sustainability, the reason, i.e. contribution to the natural environment is a very important reason. This reason was given only in four textbooks (Mathis and Jackson, 2011; Torrington, Hall, Taylor, and Atkinson, 2011; Stewart and Brown, 2014; and Opatha, 2019). This reason got $11^{\text {th }}$ rank. This may be owing to the cause that concern of the natural environment had not been a traditional consideration of HRM, and its consideration started recently because of increased natural disasters and possible dangers to human existence and business organizations' sustainability.

The findings imply that it is imperative that HRM is taught in any educational programme or professional programme in the field of Management or Business Administration. Management of human resources is a vital field of studies and is a well recognized practice of high value (Arulrajah and Opatha, 2016), being an important and challenging function for every organization (Jinadasa and Opatha, 1999). Developing a person to the level of a graduate in Management or Business Administration will not become complete without making the person exposed to teaching and learning of HRM. HRM has to be taught or learnt as a core course at the degree level of education. It is suggested that two courses are offered at the Bachelor's degree in Management or Business Administration (special 4-year programme) in order to cover the gamut of HRM. A compulsory course in HRM needs to be offered at any generalized Master's degree in Management or Business Administration. 


\section{References}

Akuratiyagamage, V.M. and Opatha, H.H.D.N.P. (2004), "Grievances of Middle Managers: An Empirical Investigation into Perceptions of Commercial Bank Branch Managers in Sri Lanka", Management Review, Vol.4, No.2, pp. 99-112.

Armstrong, M. and Taylor, S. (2014), Armstrong's Handbook of Human Resource Management, London: Kogan Page.

Arulrajah, A.A. and Opatha, H.H.D.N.P. (2016), "Analytical and Theoretical Perspectives on Green Human Resource Management: A Simplified Underpinning", International Business Research, Vol.9, No.12, pp. 153-164.

Babbie, E. (1986), The Practice of Social Research, $4^{\text {th }}$ edi., California: West Publishing.

Beach, D.S. (1985), Personnel: The Management of People At Work, $5^{\text {th }}$ edi., New York: Macmillan Publishing Company.

Beardwell, J. and Claydon, T. (2007), Human Resource Management: A Contemporary Approach, London: Prentice Hall.

Bernardin, H.J. and Russell, J.E.A. (1993), Human Resource Management: An Experiential Approach, New York: McGraw-Hill, Inc.

Bohlander, G. and Snell, S. (2017), Principles of Human Resource Management, Mason: Cengage Learning.

Bohlander, G., Snell, S., and Sherman, A. (2001), Managing Human Resources, $12^{\text {th }}$ edi., Cincinnati, Ohio: South-Western College Publishing.

Bratton, J and Gold, J. (1994), Human Resource Management: Theory and Practice, London: Macmillan.

Byars, L.L. and Rue, L.W. (2008), Human Resource Management, Boston: McGraw-Hill Irwin.

Casio, W.F. (2010), Managing Human Resources: Productivity, Quality of Work Life, Profits, $8^{\text {th }}$ edi., Boston: McGraw-Hill Irwin.

Chruden, H.J. and Sherman, A.W. (1980), Personnel Management: The Utilization of Human Resources, $6^{\text {th }}$ edi., Cincinnati, Ohio: South-Western Publishing Co.

DeNisi, A.S. and Griffin, R.W. (2008), Human Resource Management, Mason: South-Western CENGAGE Learning.

Fisher, C.D., Schoenfeldt, L.F., Shaw, J.B. (2006), Human Resource Management, $6^{\text {th }}$ edi., Boston: Houghton Mifflin Company.

French, W.L. (1978), The Personnel Management Process, $4^{\text {th }}$ edi., Dallas: Houghton Mifflin Company.

Glueck, W.F. (1979), Foundations of Personnel, Texas: Business Publications Inc.

Gomez-Mejia, L.R., Balkin, D.B., and Cardy, R.L. (2010), Managing Human Resources, Boston: Prentice Hall.

Heneman III, H.G., Schwab, D.P., Fossum, J.A., and Dyer, L.D. (1989), Personnel/Human Resource Management, New York: Richard D. Irwin, Inc.

Ivancevich, J.M. (2010), Human Resource Management, Boston: McGraw-Hill Irwin.

Jackson, S.E., Schuler, R.S., and Werner, S. (2012), Managing Human Resources, $11^{\text {th }}$ edi., Mason, OH: SOUTH-WESTERN CENGAGE Learning. 
Jinadasa, P.C.V. and Opatha, H.H.D.N.P. (1999), "An Empirical Study of Membership Participation in Trade Union Activities: Evidence From Selected Service Organizations in Sri Lanka", Sabaragamuwa University Journal, 2(1): pp.17-34.

Kleiman, L.S. (2004), Human Resource Management: A Managerial Tool for Competitive Advantage, $3^{\text {rd }}$ edi., Cincinnati, Ohio: Atomic Dog Publishing.

Lussier, R.N. and Hendon, J.R. (2013), Human Resource Management: Functions, Applications, Skill Development, California, London, New Delhi, and Singapore: SAGE Publications Ltd.

Mamoria, C. B. (1996), Personnel Management: Bombay: Himalaya Publishing House.

Mathis, R.L. and Jackson, T.H. (2011), Human Resource Management, $13^{\text {th }}$ edi., Mason, OH: SOUTH-WESTERN CENGAGE Learning.

Noe, R.A., Hollenbeck, J.R., Gerhart, B., and Wright, P.M. (2007), Human Resource Management, New Delhi: Tata McGraw-Hill Publishing Company (Indian Print).

Opatha, H.H.D.N.P. (1995), Sewamandala Kalamanakaranaya (Personnel Management), Colombo: Author Publication.

Opatha, H.H.D.N.P. (2003), Research Methods for Human Resource Management: Questions and Answers, Colombo: Author Publication.

Opatha, H.H.D.N.P. (2009), Human Resource Management: Personnel, Colombo: Department of HRM, University of Sri Jayewardenepura.

Opatha, H.H.D.N.P. (2019), Sustainable Human Resource Management: Expanding Horizons of HRM, Colombo: Department of HRM, University of Sri Jayewardenepura.

Schuler, R.S. and Youngblood, B.S.A. (1986), Effective Personnel Management, New York: West Publishing Company.

Sekaran, U. and Bougie, R. (2016), Research Methods for Business: A Skill Building Approach, $6^{\mathrm{TH}}$ edi., WILEY.

Stewart, G.L. and Brown, K.G. (2014), Human Resource Management: Linking Strategy to Practice, $3^{\text {rd }}$ edi., Hoboken, NJ: John Wiley \& Sons, Inc.

Stone, T. H. and Melt, N. M. (1983), Personnel Management in Canada, Toronto: Hott of Canada Ltd.

Torrington, D. Hall, L., Taylor, S., and Atkinson, C. (2011), Human Resource Management, $8^{\text {th }}$ edi., London: Pearson.

Werther, B. W., and Davis, K. (1996), Human Resources and Personnel Management, $4^{\text {nd }}$ edi., New York: McGraw- Hill Book Company. 